\title{
Protective effects of quercetin against cisplatin induced urogenital organ toxicity
}

\author{
Tarık Emre ŞENER $^{1}$ (D), Selin ÇADIRCI ${ }^{2}$ D) Özge ÇEVIK ${ }^{3}$ (D) , Feriha ERCAN ${ }^{4}$ (D), \\ M. Kutay KÖROĞLU 4 (D), Selin ŞAKARCAN 5 iD, Göksel ŞENER 2 * (D) \\ 1 Marmara University, School of Medicine, Department of Urology, İstanbul \\ 2 Marmara University, School of Pharmacy, Department of Pharmacology, İstanbul \\ 3 Adnan Menderes University, School of Medicine, Department of Biochemistry, Aydin \\ 4 Marmara University, School of Medicine, Department of Histology and Embriology, İstanbul \\ 5 Yale New Haven Health, Bridgeport Hospital, Connecticut, USA \\ * Corresponding Author. E-mail: gsener@marmara.edu.tr (G.Ş.); Tel. +90-216-777 5200
}

Received: 10 August 2020 / Revised: 04 September 2020/ Accepted: 05 September 2020

\begin{abstract}
Cisplatin is a chemotherapeutic agent that is the first to enter treatment from organic platinum-derived drugs. Nephrotoxicity and cytotoxicity are major factors that limit its use. The aim of the study is to investigate the possible protective effects of quercetin against cisplatin-induced urogenital organ toxicity. In our study, Sprague Dawley four month old male rats were divided into 4 groups; control + saline (SF), control + quercetin ( $20 \mathrm{mg} / \mathrm{kg}$ for 21 days), cisplatin $(7 \mathrm{mg} / \mathrm{kg}$ as a single dose $)+\mathrm{SF}$ and cisplatin + quercetin groups. After decapitation, the kidney, bladder, testis and corpus cavernosum tissue samples were taken to analyze caspase-3, an index of apoptosis, and oxidative stress parameters such as malondialdehyde (MDA), gluta-thione (GSH), and 8-hydroxy-2' -deoxyguanosine (8-OHdG). Furthermore, tissues were also examined histologically. Cisplatin caused significant increases in MDA and 8-OHdG levels, demonstrating increases in lipid peroxidation and oxidative DNA damage, respectively, in all tissues. In parallel with the oxidant stress increase, the endogenous strong antioxidant GSH levels were decreased. Caspase activity and caspase 3 expressions, which we measured as an indicator of apoptosis, increased significantly with cisplatin treatment. On the other hand, treatment with quercetin, a powerful antioxidant flavonoid, reversed these changes. Histological findings also demonstrated well-preserved tissues due to quercetin treatment. In conclusion, our results suggested that quercetin, when given with cisplatin, can be protective against the chemotherapeutic induced toxicity and thus provide therapeutic benefit.
\end{abstract}

KEYWORDS: Cisplatin; oxidative stress; quercetin; bladder; kidney; testis; corpus cavernosum.

\section{INTRODUCTION}

Platinum compounds are broad-spectrum antineoplastic drugs, and cisplatin is the first agent of this group to be utilized for treatment [1]. It is effective in various types of solid cancers (such as testicular, ovarian, bladder, prostate, head and neck cancers) and is therefore widely preferred in chemotherapy protocols. Cisplatin and its analogue carboplatin have been successfully used in the treatment of tumor types that do not respond to other treatments [2].

As with other alkylating antineoplastic drugs, cisplatin forms cross-links in DNA structure and causes DNA damage. This damage preventing DNA replication and RNA synthesis, slow cell growth especially in rapidly growing cells like cancer cells [3]. Furthermore, cross-linking can further increase the DNA damage. If DNA damage is mild, it can be repaired with DNA repair mechanisms, but if there is more DNA damage, the cell injury becomes irreversible. While this mechanism is necessary for cancer cells, DNA damage that develops in other tissues and cells, causes drug-induced toxicity [4].

Among mechanisms responsible in cisplatin cytotoxicity, reactive oxygen species (ROS) formation that causes oxidant damage is known as an important contributor [5-7]. Since ROS are known to damage lipids, proteins and nucleic acids, cisplatin could cause multiorgan oxidant damage through generation of ROS during its metabolism [4].

How to cite this article: Şener TE, Çadırcı S, Çevik Ö, Ercan F, Köroğlu MK, Şakarcan S, Şener G. Protective effects of quercetin against cisplatin induced urogenital organ toxicity. J Res Pharm. 2020; 24(5): 640-647. 
Flavonoids are low molecular weight phenolic compounds and are found in vegetables, fruits, nuts, seeds, spices and flowers [8]. Quercetin that belongs to flavonoid family, is an important antioxidant and has been reported to have beneficial effects on human health [9]. Besides its antioxidant activity, it has antiviral, anti-bacterial, anticarcinogenic and antiinflammatory effects [10]. Cisplatin toxicity was mostly studied on kidneys; however other tissues were not studied in detail. Therefore, in this study the effects of quercetin against cisplatin-induced toxicity in urogenital organs, such as kidney, bladder, corpus cavernosum and testicular tissues were investigated.

\section{RESULTS}

\subsection{Biochemical Results}

As shown in Table 1, when compared with the control group MDA levels, an index of lipid peroxidation, and 8-OHdG levels, an index of DNA damage, respectively, were found to be significantly $(p<0.05-0.001)$ increased in all tissues studied, showing cisplatin-induced increased oxidative stress. Similarly, due to cisplatin-induced oxidative stress, caspase-3 enzyme activities of tissues, an apoptotic marker, were also increased significantly $(\mathrm{p}<0.05-0.001)$. On the other hand, in the QT-treated group these oxidative stress markers were found to be decreased significantly $(\mathrm{p}<0.05-0.001)$.

When we evaluated the GSH results, it is found that CP-induced oxidative stress depleted the tissue stores of this important antioxidant.

Table 1. Malondialdehyde (MDA), glutathione (GSH) and 8-hydroxydeoxyguanosine (8-OHdG) levels in the kidney, bladder, corpus cavernosum and testicular tissues of control $(\mathrm{C})$, quercetin $(\mathrm{QT})$, cisplatin $(\mathrm{CP})$ and $\mathrm{CP}+\mathrm{QT}$ groups.

\begin{tabular}{|c|c|c|c|c|c|}
\hline & & C & QT & $\mathrm{CP}$ & $\mathrm{CP}+\mathrm{QT}$ \\
\hline \multirow{4}{*}{$\begin{array}{c}\text { MDA } \\
\text { (nmol/g tissue) }\end{array}$} & Kidney & $20.0 \pm 3.0$ & $22.2 \pm 2.1$ & $36.4 \pm 2.7 * * *$ & $20.5 \pm 1.4^{++}$ \\
\hline & Bladder & $19.1 \pm 1.2$ & $20.6 \pm 1.5$ & $31.7 \pm 2.1 * * *$ & $17.1 \pm 1.6^{+++}$ \\
\hline & C. Cavernosum & $11.4 \pm 0.4$ & $12.7 \pm 0.7$ & $17.1 \pm 1.1 * * *$ & $10.4 \pm 0.9^{++}$ \\
\hline & Testis & $11.6 \pm 1.2$ & $10.2 \pm 0.4$ & $18.6 \pm 1.5$ * & $13.9 \pm 2.4^{++}$ \\
\hline \multirow{4}{*}{$\begin{array}{c}\text { 8-OHdG } \\
\text { (ng/mg DNA) }\end{array}$} & Kidney & $8.5 \pm 0.8$ & $6.5 \pm 1.4$ & $14.9 \pm 0.6^{* * *}$ & $10.1 \pm 0.5^{++}$ \\
\hline & Bladder & $2.9 \pm 0.4$ & $4.9 \pm 0.9$ & $13.2 \pm 2.0 * * *$ & $5.8 \pm 1.1^{++}$ \\
\hline & C. Cavernosum & $6.7 \pm 0.1$ & $5.6 \pm 0.4$ & $8.8 \pm 0.4 * *$ & $3.7 \pm 0.3^{* * *},+++$ \\
\hline & Testis & $11.1 \pm 1.3$ & $7.8 \pm 1.3$ & $18.7 \pm 1.0 * * *$ & $13.1 \pm 0.8^{+}$ \\
\hline \multirow{4}{*}{$\begin{array}{c}\text { Caspase-3 activity } \\
\text { (nmol pNA/min/mg } \\
\text { protein) }\end{array}$} & Kidney & $21.1 \pm 1.2$ & $21.6 \pm 1.6$ & $35.24 \pm 3.8^{* *}$ & $24.4 \pm 1.2^{+}$ \\
\hline & Bladder & $16.1 \pm 1.4$ & $16.2 \pm 1.3$ & $22.7 \pm 1.8$ * & $16.1 \pm 0.8^{+}$ \\
\hline & C. Cavernosum & $11.2 \pm 0.9$ & $12.3 \pm 1.0$ & $17.7 \pm 0.8$ ** & $13.5 \pm 1.1^{+}$ \\
\hline & Testis & $16.7 \pm 0.6$ & $17.4 \pm 1.6$ & $33.8 \pm 4.9 * * *$ & $22.7 \pm 1.6^{+}$ \\
\hline \multirow{4}{*}{$\begin{array}{c}\text { GSH } \\
(\mu \mathrm{mol} / \mathrm{g} \text { tissue })\end{array}$} & Kidney & $2.5 \pm 0.2$ & $2.1 \pm 0.1$ & $1.5 \pm 0.2 * *$ & $2.6 \pm 0.3^{++}$ \\
\hline & Bladder & $3.2 \pm 0.2$ & $3.1 \pm 0.3$ & $1.8 \pm 0.1$ ** & $3.1 \pm 0.2^{+}$ \\
\hline & C. Cavernosum & $1.2 \pm 0.1$ & $1.1 \pm 0.2$ & $0.6 \pm 0.1$ * & $1.2 \pm 0.1^{+}$ \\
\hline & Testis & $2.8 \pm 0.2$ & $2.5 \pm 0.2$ & $1.1 \pm 0.1$ *** & $1.9 \pm 0.1 * *,++$ \\
\hline
\end{tabular}

${ }^{*} \mathrm{p}<0.05,{ }^{* *} \mathrm{p}<0.01,{ }^{* * *} \mathrm{p}<0.001$ : compared with control group.

$+p<0.05,++p<0.01,+++p<0.001$ : compared with CP group. 
The expressions of caspase- 3 enzyme in kidney, bladder, corpus cavernosum and testis tissues were found to be significantly increased ( $\mathrm{p}<0.01$ ) compared to the control (Figure 1 ). On the other hand, caspase-3 enzyme expressions of all the tissues studied in the quercetin treated $\mathrm{CP}$ group decreased significantly ( $\mathrm{p}$ $<0.05)$ compared to the un-treated cisplatin administered group. When compared to the control group, although kidney and testicular tissues of caspase expressions of QT-treated CP rats were found to be closer to the control, cavernosal and bladder tissues enzyme expressions were still higher than that of the control.
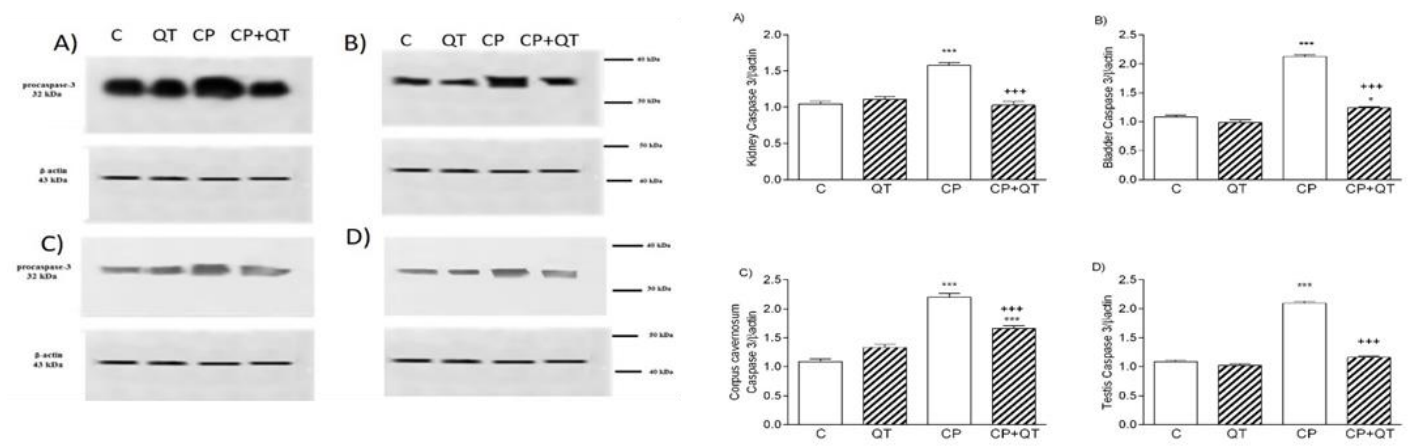

Figure 1. Caspase-3 western blotting (right) and their densities (left) in the A) kidney, B) bladder, C) corpus cavernosum and D) testis tissues of control (C), quercetin (QT), cisplatin $(\mathrm{CP})$, and $\mathrm{CP}+\mathrm{QT}$ groups.

\subsection{Histological Results}

In the $\mathrm{C}$ and QT groups, regular morphology of kidney, urinary bladder, testis and corpus cavernosum (Figure 2A, B - 5A, B) was observed.

In the $\mathrm{CP}$ group, severe degeneration of the tubular epithelium, dilatation of Bowman's space and glomerular congestion and inflammatory cell infiltration in the kidney were observed (Figure 2C). The urinary bladder (Figure 3C) showed disorganization of the urothelium with desquamation in some region and mild inflammatory cell infiltration in this group. Corpus cavernosum (Figure 4C) showed mild endothelial degeneration, inflammatory cell infiltration and disorganized smooth muscle cells and testis tissue (Figure 5C) showed degenerated and atrophic tubules in the CP group.

Cisplatin and quercetin applied groups showed mild degeneration in renal corpuscles and tubules in kidney (Figure 2D), quite regular urothelium in urinary bladder (Figure 3D), quite regular endothelium and smooth muscle cells in corpus cavernosum, (Figure 4D) and decreased number of degenerated and atrophic tubules in testis (Figure 5D).
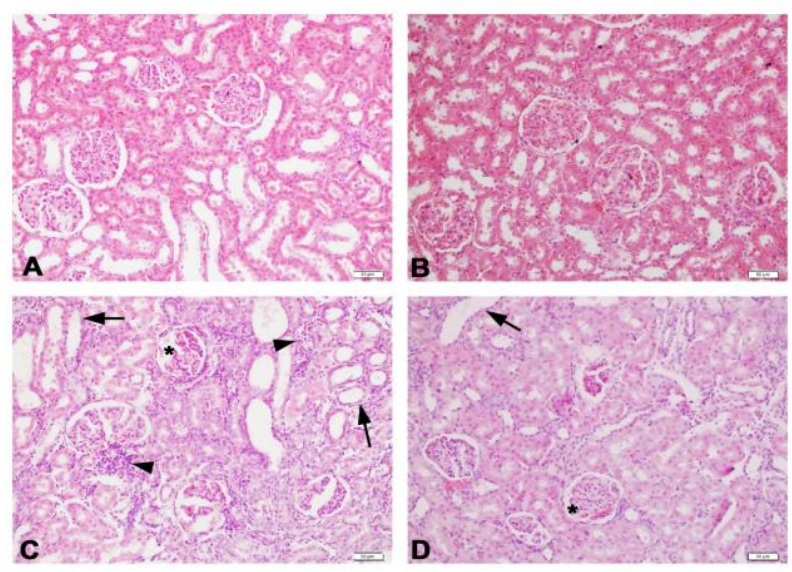

Figure 2. Representative photomicrographs of kidney in experimental groups. Regular parenchyma morphology of kidney in control groups (A, B); glomerular congestion, degenerated tubules and inflammatory cell infiltration in cisplatin applied group (C); decreased glomerular congestion, degenerated tubules and inflammatory cell infiltration in cisplatin and quercetin applied group (D). Bowman's space $\left(^{*}\right)$, degenerated tubules (arrow) and inflammatory cell infiltration (arrowhead). H\&E staining, scale bars: $50 \mathrm{~mm}$. 

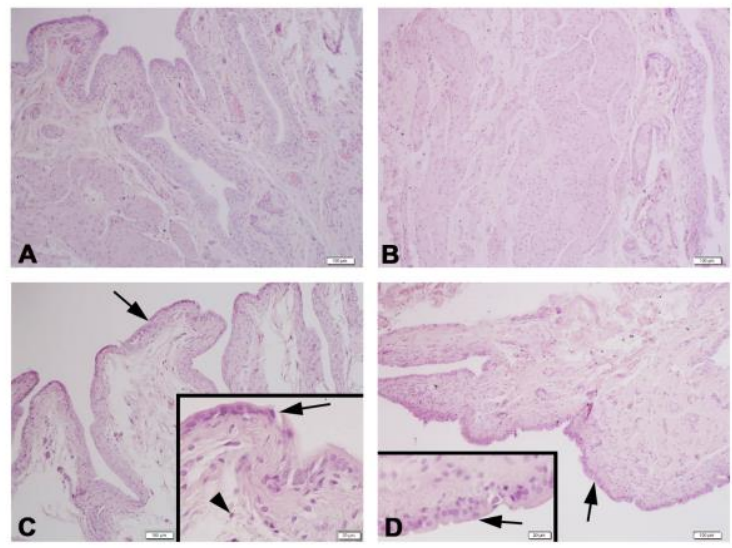

Figure 3. Representative photomicrographs of urinary bladder in experimental groups. Regular mucosa with urothelium in control groups (A, B); degeneration of the urothelium in some region in cisplatin applied group (C); quite regular urothelium in cisplatin and quercetin applied group (D); Arrowhead: inflammatory cell, H\&E staining, scale bars: $100 \mu \mathrm{m}$ and inset: $20 \mu \mathrm{m}$.
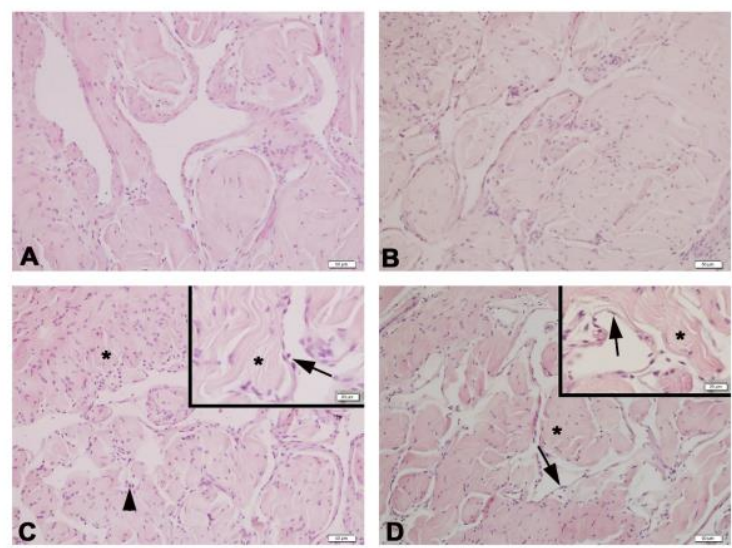

Figure 4. Representative photomicrographs of corpus cavernosum in experimental groups. Regular corpus cavernosum morphology in control groups (A, B); mild degeneration of endothelial cells, inflammatory cells and disorganized smooth muscle cells in cisplatin applied group $(\mathrm{C})$; quite regular endothelium and smooth muscle cells in cisplatin and quercetin applied group (D). Arrow: endothelium, arrowhead: inflammatory cell, *: smooth muscle cells, H\&E staining, scale bars: $50 \mu \mathrm{m}$ and inset: $20 \mu \mathrm{m}$.
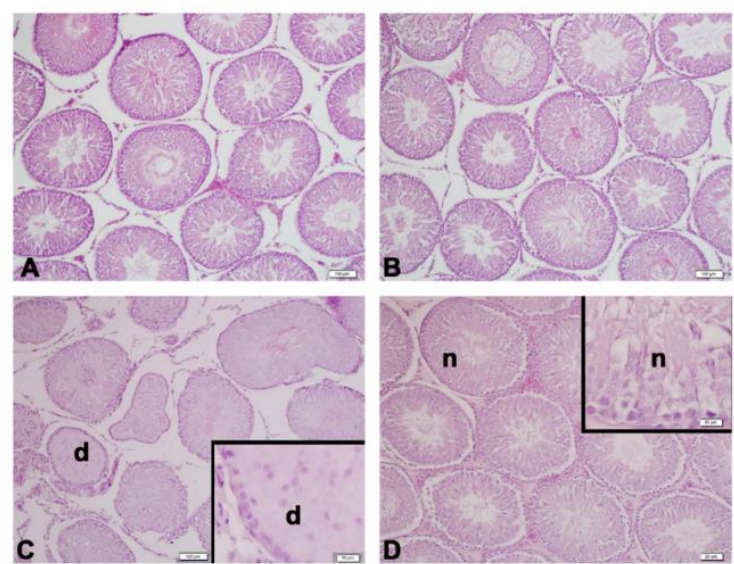

Figure 5. Representative photomicrographs of testis in experimental groups. Normal testis morphology with seminiferous tubules in control groups (A, B). Degenerated seminiferous tubules (d) with irregular arrangement of germinal and Sertoli cells with loss of intercellular tight junctions in cisplatin applied group (C); increased number of normal (n) tubules in cisplatin and quercetin applied group (D). H\&E staining, Scale bar: $100 \mu \mathrm{m}$ and inset: $20 \mu \mathrm{m}$. 


\section{DISCUSSION}

Cisplatin is a chemotherapeutic drug that has been used for many years in the treatment of many types of cancers such as head and neck, solid testicle, prostate, and bladder. Dose-related nephrotoxicity and cytotoxicity are the most important side effects that limit its use [11, 12]. As a result of single dose cisplatin administration, the drug accumulates locally in the proximal tube, while long-term cisplatin administration causes damage to the proximal tube, as well as distal tubule, glomeruli and interstitial connective tissue, causing chronic renal failure [12-14]. On the other hand, the importance of oxidative stress in CP toxicity was clearly emphasized and studies with antioxidants in cisplatin toxicity have positive results in the literature. In light of this information, we examined whether quercetin has protective effects against cisplatin toxicity in urogenital tissues.

In the case of oxidative stress, increased production of reactive oxygen species causes damage to cell components (lipid, protein DNA), while antioxidant defenses weaken [15, 16]. Sener et al has demonstrated the protective effects of melatonin, a powerful antioxidant, against $\mathrm{CP}$ toxicity. They suggested that $\mathrm{CP}$ caused depletion of GSH stores, which is associated with increases in lipid peroxidation in kidney tissues [17]. Similarly, in the study of Mayada et al. following a single dose CP, administration of curcumin nano particules effectively protected against hepatic and renal damage through its antioxidant and anti-inflammatory properties [18]. Cisplatin toxicity is mostly examined in kidney, liver and testicular tissue; however, there is little study in bladder and cavernous tissue and there is no quercetin study in these urologenital structures. In the study of Malik et al., a citrus flavonoid nobiletin, that has antioxidant anti-inflammatory and antiapoptotic properties, was investigated against $\mathrm{CP}$ toxicity. Following $\mathrm{CP}$ administration, increased blood urea nitrogen and creatinine levels demonstrated impaired kidney function and increased MDA levels demonstrated increased oxidative stress. In a parallel with increased oxidative stress, CP had caused decreased in antioxidants; GSH levels and SOD and CAT activities. Furthermore, CP caused apoptosis where Bax and caspase expressions were increased and Bcl-2 was decreased [19]. On the other hand, nobiletin had depressed the activation of apoptotic pathway, decreased DNA damage, and thus protected kidney tissues and functions.

In another study, CP toxicity was investigated in testis and the data demonstrated decreased testicular and epididimal weight, sperm count and motility, GSH-Px and SOD activities and GSH levels while MDA levels were found to be increased. On the other hand, treatment with grape seed extract attenuated CPinduced lipid peroxidation, oxidative stress and thus, harmful effects of $\mathrm{CP}$ on genital organs. Accordingly, they concluded that grape seed extract could be protective against testicular injury caused by CP [20].

Salem et al examined the protective effects of selenium and lycopene administration against the CPinduced oxidative stress and demonstrated decreased lipid peroxidation and attenuation of genital organ injury [21]. Similarly, Almaghrabi et al., after applying quercetin to rats for 30 days following 5 days of cisplatin treatment, they investigated antioxidant gene expression and antioxidant enzyme activity in kidneys and observed that CAT, SOD, GPx and GR values decreased in rats administered with cisplatin compared to the control group. On the other hand, these antioxidants were increased after quercetin treatment [22]. Furthermore, vitamin $\mathrm{C}$ and $\mathrm{E}$ values were also measured in these rats after cisplatin administration and found that antioxidant vitamin levels were also decreased in CP treated rats [22]. In our study, MDA levels, which is an indicator of lipid peroxidation, in all tissues as kidney, bladder, testicle and corpus cavernosum of cisplatintreated groups, were found to be significantly increased and are in accordance with the literature. Furthermore, cisplatin toxicity was depressed with quercetin treatment in these organs. Quercetin is an antioxidant belonging to the flavon group found in vegetables and fruits, which has been used for therapeutic purposes for many years. In addition, it has been shown to be antiviral, antiinflammatory and anticarcinogenic $[9,10]$. In the study of Elbe et al., STZ-induced experimental diabetic rats were treated with melatonin, quercetin and resveratrol, and MDA, SOD, GSH and CAT values were measured. The MDA value was found to be high in diabetic rats, SOD, GSH and CAT values were found to be lower than the control. While, the MDA value decreased after the antioxidant treatment, CAT and GSH activities have increased [23].

The antiapoptotic properties of quercetin and its protective effects on tissues have been studied in various organs. It has been shown that experimental vascular calcification induced by inorganic phosphate with both in-vitro and in-vivo, causes increased oxidative stress, mitochondrial dysfunction and increased apoptosis. In contrast, quercetin has been reported to inhibit mitochondria-dependent apoptotic events, cytochrome-c release, and thus prevent vascular calcification by inhibiting oxidant damage [24]. Park et al. had investigated quercetin against ischemic brain injury and demonstrated that ischemia-induced glutamate and caspase-3 increases were effectively suppressed [25]. Examining the effects of quercetin supplementation against aging caused by D-galactose in the pancreatic and kidney tissues, El-Far and colleagues reported that 
this substance may be effective in preventing aging-related oxidant damage and suppress apoptotic and inflammatory events [26]. Furthermore, in doxorubicin-induced cardiotoxicity, quercetin treatment, by increasing the antioxidant levels, suppressed ROS formation and caspase activity and thereby corrected the mitochondrial function [27]. In our study, CP stimulated apoptosis by oxidative stress and as a result, both activity and procaspase expression of caspase increased in tissues. In contrast, with quercetin treatment, apoptosis was reduced in urogenital structures.

8-OHdG is one of the main products of the oxidation of DNA. The 8-OHdG concentration in the cell is a measure of oxidative stress. In the study of Tsuji et al, rats were treated with dimethylthiourea (DMTU) following cisplatin administration for 5 days. Increased serum creatinine, 8-OHdG, and tubular damage, by $\mathrm{CP}$, significantly inhibited with DMTU. DMTU also inhibited the increase in Bax levels seen in the CP group. These findings have shown quercetin to be protective against acute renal damage due to cisplatin and prevent apoptosis in Bax-mediated renal tubular cells [28]. Similarly, according to our results, DNA damage was significantly increased in all tissues as a result of cisplatin treatment while DNA damage was found to be significantly lower after quercetin treatment.

\section{CONCLUSION}

As a conclusion, the present study demonstrated that $\mathrm{CP}$ caused oxidative damage in urogenital organs while quercetin administration protected the tissues. However, more extensive experimental and clinical research is needed to employ quercetin for this purpose in the clinic.

\section{MATERIALS AND METHODS}

\subsection{Animals and ethics}

In our study, weighing 250-300 g male Sprague Dawley rats were used. During the experiment, rats were kept in $20^{\circ} \mathrm{C} \pm 2$ temperature and laboratory conditions with 12 hours light/12 hours dark environment. This study was done with the approval of Marmara University Animal Ethics Committee (No: 99. 2013.mar).

\subsection{Groups and cisplatin toxicity}

Rats were divided into 4 groups as control $(\mathrm{C})$, quercetin $(\mathrm{QT})$, cisplatin $(\mathrm{CP})$ and $\mathrm{CP}+\mathrm{QT}$. Control rats were administered saline $(0.1 \mathrm{ml} / 100 \mathrm{~g})$ intraperitoneally (ip) once, followed by saline administration orally for 21 days. Similarly, in the QT group rats were administered saline ip once, followed by QT at a dose of 20 $\mathrm{mg} / \mathrm{kg}$, orally for 21 days. In the $\mathrm{CP}$ and $\mathrm{CP}+\mathrm{QT}$ groups, rats were given single dose of $\mathrm{CP}(7 \mathrm{mg} / \mathrm{kg}$, ip) and followed by orally saline and QT for 21 days, respectively. The doses of cisplatin and quercetin are based on the previous studies [7,29]. After 21 days of treatment, animals were decapitated and tissue (kidney, bladder, corpus cavernosum and testis) samples were taken.

Oxidative damage and apoptosis measurements were made in tissues by the analyses of malondiladehyde (MDA), glutathione (GSH), superoxide dismutase (SOD), caspase-3 and DNA oxidation.

\subsection{Biochemical analysis}

The kidney, bladder, testicle and cavernosum tissues were removed immediately after decapitation, were washed with saline, and dried. The method of Beuge and Aust [30] was used for MDA determination and Beutler method [31] was used for GSH. 10\% homogenates of tissues were prepared with $150 \mathrm{mM} \mathrm{KCl}$ solution using Ika Werk homogenizer on ice.

8-hydroxy-2'-deoxy-guanosine (Oxi SelectTM Oxidative DNA Damage Elisa Kit, Cell Biolabs, US) levels, which reflect the oxidative DNA damage, were evaluated in tissue homogenates using commercially available kits.

Caspase- 3 activity assay was performed using the caspase- 3 cellular activity assay kit (Calbiochem, San Diego, CA) according to the manufacturer's instructions. The DEVDpNA cleavage activity was calculated as $\mathrm{pmol} / \mathrm{min} / \mathrm{mg}$ protein. Protein concentration in tissue samples was determined using Bradford method [32].

Caspase-3 protein expression was measured directly by Western blot using a monoclonal rat anticaspase-3 and cleaved caspase-3 (clv-cas3) antibodies. Samples were homogenized with cell lysis buffer and then centrifuged sample supernatant was collected for determining immunobloting assay. Samples were resolved on $12 \%$ SDS-PAGE and transferred to nitrocellulose membrane. The membrane was blocked with $5 \%$ nonfat skimmed milk powder then washed with TBST and incubated overnight with primary antibody (1:500 monoclonal rat anti-caspase-3 sc-56055; anti-b-actin, sc-47778 from Santa Cruz Biotechnology, clv-casp3 9664 
from Cell Signaling). The membrane was incubated with HRP conjugated secondary antibody for $2 \mathrm{~h}$. After the incubation, the membrane was developed with chemiluminescence reagents (sc-2048, Santa Cruz Biotechnology L kit) and exposed to Fuji Super RX fi lm (47410, Tokyo, Japan). Protein bands were analyzed using "Image J Programme Optical Density Analysis Software" (NIH, USA). Signals were normalized with respect to $\beta$-actin.

\subsection{Histological evaluation}

For light microscopy, kidney, urinary bladder, corpus cavernosum and testis samples were fixed in 10\% buffered formalin for $48 \mathrm{~h}$ and processed for routine paraffin embedding. Approximately $7-\mu \mathrm{m}$ thick sections were stained with hematoxylin and eosin (H\&E). All of the stained sections were observed and photographed with a digital camera (Olympus C-5060, Tokyo, Japan) attached to a photomicroscope (Olympus BX51, Tokyo, Japan). The histological examination was performed by a histologist unaware of the treatment groups.

Acknowledgements: This study was supported by Marmara University Scientific Research Projects Commission under the grant no: SAG-C-YLP-2802140040

Author contributions: Concept - G.Ş., T.E.Ş.; Design - G.Ş., S.Ç., T.E.Ş., S.Ş.; Supervision -G.Ş., T.S., S.Ç.; Resources G.Ş., T.E.Ş., S.Ş.; Materials - G.Ş., Ö.Ç., S.Ç., F.E., M.K.K.; Data Collection and/or Processing - G.Ş., Ö.Ç., S.Ç., F.E., M.K.K.; Analysis and/or Interpretation - G.Ş., Ö.Ç., S.Ç., F.E., M.K.K.; Literature Search - G.Ş., T.E.Ş., S.Ş.; Writing G.Ş., T.E.Ş., S.Ş; F.E.; Critical Reviews -T.E.Ş., S.Ç., Ö.Ç., F.E., M.K.K., S.Ş. G.Ş.

Conflict of interest statement: The authors declared no conflict of interest.

Ethics committee approval: This study was approved by Marmara University Animal Ethics Committee with the number of 99.2013.mar on September 13, 2013.

\section{REFERENCES}

[1] Rosenberg B. Fundamental studies with cisplatin. Cancer. 1985; 55(10): 2303-2316. [CrossRef]

[2] Florea AM, Büsselberg D. Cisplatin as an anti-tumor drug: cellular mechanisms of activity, drug resistance and induced side effects. Cancers (Basel). 2011;3(1): 1351-1371. [CrossRef]

[3] Dos Santos NA, Carvalho Rodrigues MA, Martins NM, dos Santos AC. Cisplatin-induced nephrotoxicity and targets of nephroprotection: an update. Arch Toxicol. 2012; 86: 1233-1250. [CrossRef]

[4] Deavall DG, Martin EA, Horner JM, Roberts R. Drug-induced oxidative stress and toxicity. J Toxicol. 2012; 2012: 645460. [CrossRef]

[5] Marullo R, Werner E, Degtyareva N, Moore B, Altavilla G, Ramalingam SS, Doetsch PW. Cisplatin induces a mitochondrial-ROS response that contributes to cytotoxicity depending on mitochondrial redox status and bioenergetic functions. PLoS ONE. 2013; 8(11): e81162. [CrossRef]

[6] Yu W, Chen Y, Dubrulle J, Stossi F, Putluri V, Sreekumar A, Putluri N, Baluya D, Lai SY, Sandulache VC. Cisplatin generates oxidative stress which is accompanied by rapid shifts in central carbon metabolism. Sci Rep. 2018; 8(1): 4306. [CrossRef]

[7] Chirino YI, Pedraza-Chaverri J. Role of oxidative and nitrosative stress in cisplatin-induced nephrotoxicity. Exp Toxicol Pathol. 2009; 61(3): 223-42. [CrossRef]

[8] Erlund I. Review of the flavonoids quercetin, hesperetin, and naringenin. Dietary sources, bioactivities, bioavailability, and epidemiology. Nutrition Res. 2004; 24: 851-874. [CrossRef]

[9] Anand David AV, Arulmoli R, Parasuraman S. Overviews of biological importance of quercetin: A bioactive flavonoid. Pharmacogn Rev. 2016; 10(20): 84-89. [CrossRef]

[10] Materska M. Quercetin and its derivatives: chemical structure and bioactivity. Pol J Food Nutr Sci. 2008; 58(4): 40713.

[11] Kuhlmann MK, Burkhardt G, Köhler H. Insights into potential cellular mechanisms of cisplatin nephrotoxicity and their clinical application. Nephrol Dial Transplant. 1997; 12(12): 2478-80. [CrossRef]

[12] Peres LA, da Cunha AD. Acute nephrotoxicity of cisplatin molecular mechanisms. Jr. J Bras Nefrol. 2013; 35(4): 33240. [CrossRef]

[13] Hanigan MH, Devarajan P. Cisplatin nephrotoxicity: molecular mechanisms. Cancer Ther. 2003; 1: 47-61. 
[14] Sánchez-González PD, López-Hernández FJ, López-Novoa JM, Morales AI. An integrative view of the pathophysiological events leading to cisplatin nephrotoxicity. Crit Rev Toxicol. 2011; 41: 803-821. [CrossRef]

[15] Lien Ai Pham-Huy, Hua He, Chuong Pham-Huy. Free Radicals, Antioxidants in Disease and Health. Int J Biomed Sci. 2008; 4(2): 89-96.

[16] Knight JA. Review: Free radicals, antioxidants, and the immune system. Ann Clin Lab Sci. 2000; 30(2): 145-158.

[17] Sener G, Satiroglu H, Kabasakal L, Arbak S, Oner S, Ercan F, Keyer-Uysal M. The protective effect of melatonin on cisplatin nephrotoxicity. Fundam Clin Pharmacol. 2000; 14(6): 553-560. [CrossRef]

[18] El-Gizawy MM, Hosny EN, Mourad HH, Abd-El Razik AN. Curcumin nanoparticles ameliorate hepatotoxicity and nephrotoxicity induced by cisplatin in rats Naunyn Schmiedebergs Arch Pharmacol. 2020; 393(10): $1941-1953$. [CrossRef]

[19] Malik S, Bhatia J, Suchal K, Gamad N, Dinda AK, Gupta YK, Arya DS. Nobiletin ameliorates cisplatin-induced acute kidney injury due to its anti-oxidant, anti-inflammatory and anti-apoptotic effects. Exp Toxicol Pathol. 2015; 67(7-8): 427-433. [CrossRef]

[20] Zhao YM, Gao LP, Zhang HL, Guo JX, Guo PP. Grape seed proanthocyanidin extract prevents DDP-induced testicular toxicity in rats. Food Funct. 2014; 5(3): 605-611. [CrossRef]

[21] Salem EA, Salem NA, Maarouf AM, Serefoglu EC, Hellstrom WJ. Selenium and lycopene attenuate cisplatin-induced testicular toxicity associated with oxidative stress in Wistar rats. Urology. 2012; 79(5): 1184.e1-6. [CrossRef]

[22] Almaghrabi OA. Molecular and biochemical investigations on the effect of quercetin on oxidative stress induced by cisplatin in rat kidney. Saudi J Biol Sci. 2015; 22(2): 227-231. [CrossRef]

[23] Elbe H, Esrefoglu M, Vardi N, Taslidere E, Ozerol E, Tanbek K. Melatonin, quercetin and resveratrol attenuates oxidative hepatocellular injury in streptozotocin-induced diabetic rats. Hum Exp Toxicol. 2015; 34(9): 859-868. [CrossRef]

[24] Cui L, Li Z, Chang X, Cong G, Hao L. Quercetin attenuates vascular calcification by inhibiting oxidative stress and mitochondrial fission. Vascul Pharmacol. 2017; 88: 21-29. [CrossRef]

[25] Park DJ, Jeon S-J, Kang J-B, Koh PO. Quercetin Reduces Ischemic Brain Injury by Preventing Ischemia-induced Decreases in the Neuronal Calcium Sensor Protein Hippocalcin. Neuroscience. 2020; 430: 47-62. [CrossRef]

[26] El-Far AH, Lebda MA, Noreldin AE, Atta MS, Elewa YHA, Elfeky M, Mousa SA. Quercetin Attenuates Pancreatic and Renal D-Galactose-Induced Aging-Related Oxidative Alterations in Rats. Int J Mol Sci. 2020; 21(12): 4348. [CrossRef]

[27] Chen X, Peng X, Luo Y, You J, Yin D, Xu Q, He H, He M. Quercetin protects cardiomyocytes against doxorubicininduced toxicity by suppressing oxidative stress and improving mitochondrial function via 14-3-3 $\gamma$. Toxicol Mech Methods. 2019; 29(5): 344-354. [CrossRef]

[28] Tsuji T, Kato A, Yasuda H, Miyaji T, Luo J, Sakao Y, Ito H, Fujigaki Y, Hishida A.The dimethylthiourea-induced attenuation of cisplatin nephrotoxicity is associated with the augmented induction of heat shock proteins. Toxicol Appl Pharmacol. 2009; 234(2): 202-208. [CrossRef]

[29] Cevik O, Erşahin M, Sener TE, Tinay İ, Tarcan T, Çetinel Ş, Şener A, Toklu HZ, Şener G. Beneficial effects of quercetin on rat urinary bladder after spinal cord injury. J Surg Res. 2013; 183(2): 695-703. [CrossRef]

[30] Buege JA, Aust SD. Microsomal lipid peroxidation. Methods Enzymol. 1978; 52: 302-310. [CrossRef]

[31] Beutler E. Glutathione in red blood cell metabolism. A manual of biochemical methods. New York: Grune and Stratton; 1975. pp. 112-114.

[32] Bradford, M., 1976. A Rapid and Sensitive Method for the Quantitation of Microgram Quantities of Protein Utilizing the Principle of Protein-Dye Binding. Analytical Biochem. 72(1-2), pp. 248-254. [CrossRef]

This is an open access article which is publicly available on our journal's website under Institutional Repository at http://dspace.marmara.edu.tr. 